\title{
Social Conditioning of Health Behaviors among Adults in Croatia: the CroHort Study
}

\author{
Sanja Musić Milanović1,2, Davor Ivanković1, Kristina Fišter1, Tamara Poljičanin ${ }^{2}$, Petrana Brečićc and \\ Silvije Vuletić ${ }^{1}$ \\ ${ }^{1}$ University of Zagreb, School of Medicine, »Andrija Štampar« School of Public Health, Department of Medical Statistics, \\ Epidemiology and Medical Informatics, Zagreb, Croatia \\ 2 University of Zagreb, Merkur University Hospital, Vuk Vrhovec University Clinic, Zagreb, Croatia \\ ${ }^{3}$ University of Zagreb, University Hospital of Psychiatry Vrapče, Zagreb, Croatia
}

\begin{abstract}
A B S T R A C T
The aim of this study was to examine the social conditioning of health behaviors of adults in Croatia, based on the data from Croatian Adult Health Survey 2003. This cross-sectional study on a representative random sample of 9070 Croatian adults showed that obesity was significantly and socially conditioned in women, whereas for men the indication of social conditioning has not reached a statistically significant level. Health behaviors were socially conditioned in both sexes. Men's living habits were more irregular than those of women. Compared with women, men consumed more cured meat products, consumed alcohol excessivelly and smoked cigarettes more often, whereas they ate less fruits and vegetables. Health promotion strategies based on the behavioral correlates of overweight and obesity are needed to prevent excess weight gain in the Croatian population. While for men a unique educational model is applicable, women require more specialized programs, adapted to their social background.
\end{abstract}

Key words: socioeconomic strata, lifestyle behaviors, CAHS

\section{Introduction}

Lifestyle and health-related behaviors are recognized as major determinants of morbidity and mortality worldwide $^{1-3}$. Concurrently, there is evidence to suggest that the socioeconomic differences in morbidity and mortality have increased ${ }^{4-6}$. The higher prevalence of unhealthy behaviors in lower socioeconomic positions ${ }^{7-9}$ is seen to be one of the mechanisms linking lower socioeconomic position to worse health ${ }^{10,11}$. Combinations of potentially modifiable behavioral factors such as smoking, alcohol consumption, dietary patterns, physical activity, and body mass index have been shown to explain $12 \%$ to $54 \%$ of the socioeconomic differences in mortality ${ }^{12-17}$. In those studies, health behaviors have typically been assessed at only one point in time, assuming implicitly that they remain constant over time.

However, major changes have occurred in population lifestyles. These include the decreasing prevalence of smoking ${ }^{18}$ and a remarkable increase in obesity since the $1990 \mathrm{~s}^{19}$. Given that changes in health behaviors may be socially patterned ${ }^{20,21}$, previous studies with a single as- sessment of behaviors may have provided an inaccurate estimation of their contribution to the association between socioeconomic position and health behaviors.

\section{Sample and Methods}

\section{Sample}

This study was based on the Croatian Adult Health Survey (CAHS) 2003 data. The sample encompassed a representative sample of the adult Croatian population, distributed within six regions of Croatia. The sample consisted of 9070 responses, obtained by the public health nurses during face-to-face interviews in the respondents' houses.

As a first step, the total sample was allocated to the six regions proportionally to the square root of the estimated population in each region - this allocation strategy produces reliable estimates at both regional and country level. The country was stratified in 20 design 
strata which were based on city type (town/municipality) and counties. As the next step, sample size of each region was proportionally allocated among the design strata. Within each stratum, a sample of towns/municipalities was independently selected using a probability-proportional-to-size systematic random approach which allowed selection of some larger units more than once. In that case, the resulting sample size of the dwellings from these units was increased accordingly. At the first stage, 85 towns/municipalities were selected in a sample. A sample of segments was then independently selected within each selected town/municipality using a probability-proportional-to-size systematic random approach. A segment encompassed area of approximately 100-150 dwellings and was used to cluster the sample in order to facilitate data collection. A sample of approximately 10 15 households was independently selected within each segment using a systematic random approach. During visits, interviewers listed names of everybody aged 18 years and over living in the selected household and used a table of random numbers to select one individual who was then included in the sample of this survey.

\section{Variables}

Self-reported body weight and height were used to calculate body mass index (BMI). BMI was calculated as weight in kilograms divided by the square of height in meters. Respondents with BMI of $30 \mathrm{~kg} \mathrm{~m}^{-2}$ or higher were classified as obese.

The health behavior information was based on self-reported information from responders. For present study, data on one key indicator from each of the four areas of health behavior were chosen. The variable describing smoking prevalence was "smoking index « based on several questions concerning duration of smoking in years and current smoking status and then dichotomized as daily and occasional smokers and others. Among responders who answered that they drink alcohol, binge drinking was positive if responders drank six or more spirits at once. People were asked what kind of fat they mostly used for food preparation at home. This variable was dichotomized as vegetable oil users and others. Information about leisure-time physical exercise was elicited in the following question: "How often do you engage in physical exercise in your free-time for at least $30 \mathrm{~min}$ causing you to be at least mildly short of breath or to perspire?«. Possible responses were: daily, 4-6 times per week, 2-3 times per week, once per week, 2-3 times per month, a few times a year or less, or I cannot exercise because of an illness or disability «. The variable was divided into two categories: frequent exercise (2-3 times per week or more) and others.

\section{Statistical analysis}

Statistical analysis was performed using SPSS (version 14.01; License: Croatian National Institute of Public Health, SPSS ID: 729038). All confidence intervals (CI) were calculated with 95\% probability levels. BOOTVARE_V21.SPS Program (Version 2.1; author: Statistics
Canada) was used for calculating confidence intervals by using »bootstrap « method which takes into account sample design information when calculating variance estimates and measures the potential size of the samp$\operatorname{ling}^{22,23}$

\section{Results}

Men in Croatia have more unhealthy habits than women. This study of behavioral risk factors for obesity in adult men and women in Croatia showed that significantly higher percentage of men than women eat cured meat products at least once a week or more often, consume alcohol excessively and smoke cigarettes. In men, $64.41 \%$ (95\% CI 62.11-66.77) consumed cured meat products once a week or more often, which is significantly higher than in women $(45.70 \%$, 95\% CI 43.76-47.48). Also $16.54 \%$ (95\% CI 16.10-16.99) men compared to 8.36\% (95\% CI 8.01-8.85) women excessively consumed alcohol, which is a statistically significant difference. Men in Croatia have a significantly higher smoking prevalence rate $(37.90 \%, 95 \%$ CI 35.34-40.45) than women in Croatia $(25.15 \%, 95 \%$ CI 23.66-26,67). Women ate fruits and vegetables more frequently than men. Significantly higher percentage of women $(77.83 \%$, 95\% CI 75.85$79.78)$ than men $(71.53 \%, 95 \%$ CI $68.34-74.68)$ have consumed fruits and vegetables on a daily basis. There were no significant differences between men and women with regard to use of animal fats to prepare meals at home or participation in leisure-time physical activity (Table 1).

No consistent pattern in the use of animal fats in food preparation in either men or women was found. In both men and women, it is evident that the proportion of people who frequently (once a week and more often) consumed cured meat products significantly decreases with

TABLE 1

SHARE OF BEHAVIORAL RISKS OF OBESITY IN THE ADULT POPULATION OF CROATIA, DISTRIBUTION BY GENDER

\begin{tabular}{lccc}
\hline & $\%$ & $95 \%$ CI & CV (\%) \\
\hline Men & & & \\
Animal fats & 27.23 & $25.03-29.52$ & 4.24 \\
Cured meat products & 64.41 & $62.11-66.77$ & 1.82 \\
Fruits and vegetables & 20.40 & $17.23-23.57$ & 2.31 \\
Alcoholic beverages & 16.54 & $16.10-16.99$ & 1.38 \\
Smoking & 37.90 & $35.34-40.45$ & 3.52 \\
Physical activity & 56.85 & $52.88-60.89$ & 3.64 \\
\hline Women & & & \\
Animal fats & 25.31 & $23.14-27.27$ & 3.85 \\
Cured meat products & 45.70 & $43.76-47.48$ & 2.08 \\
Fruits and vegetables & 77.83 & $75.85-79.78$ & 1.27 \\
Alcoholic beverages & 8.36 & $8.01-8.85$ & 2.54 \\
Smoking & 25.15 & $23.66-26.67$ & 3.02 \\
Physical activity & 51.92 & $47.86-55.88$ & 3.94 \\
\hline
\end{tabular}

$\mathrm{CI}$ - confidence inerval, CV - coefficient of variation 
TABLE 2

SHARE OF PERSONS USING ANIMAL FAT IN FOOD PREPARATION, WHO FREQUENTLY CONSUMED CURED MEAT AND PEOPLE WHO REGULARLY CONSUME FRUITS AND/OR VEGETABLES IN THE TOTAL ADULT POPULATION OF CROATIA, DISTRIBUTION BY SEX AND AGE

\begin{tabular}{|c|c|c|c|c|c|c|c|c|c|}
\hline & $\begin{array}{l}\text { Persons using } \\
\text { animal fats in } \\
\text { food prepara- } \\
\text { tion }(\%)\end{array}$ & $95 \% \mathrm{CI}$ & $\mathrm{CV}(\%)$ & $\begin{array}{l}\text { Persons who } \\
\text { frequently eat } \\
\text { cured meat } \\
\text { products }(\%)\end{array}$ & $95 \% \mathrm{CI}$ & $\mathrm{CV}(\%)$ & $\begin{array}{l}\text { Persons who } \\
\text { regularly con- } \\
\text { sume fruit } \\
\text { and/or vegeta- } \\
\text { bles }(\%)\end{array}$ & $95 \% \mathrm{CI}$ & $\mathrm{CV}(\%)$ \\
\hline Total & 26.22 & $24.44-28.00$ & 3.52 & 54.50 & $52.8-56.2$ & 1.61 & 74.90 & $72.7-77.0$ & 1.50 \\
\hline \multicolumn{10}{|c|}{ Men (years) } \\
\hline $18-24$ & 26.23 & $17.86-344.4$ & 16.09 & 87.89 & $83.11-92.56$ & 2.82 & 72.42 & $63.12-81.81$ & 6.66 \\
\hline $25-34$ & 22.02 & $16.48-27.57$ & 12.89 & 78.62 & $72.44-84.71$ & 4.00 & 69.78 & $61.43-78.22$ & 6.25 \\
\hline $35-44$ & 29.51 & 23.66-35.33 & 10.11 & 68.24 & $61.77-74.56$ & 4.76 & 72.43 & $66.07-78.78$ & 4.55 \\
\hline $45-54$ & 30.89 & $26.91-34.89$ & 6.56 & 61.14 & $56.19-66.00$ & 4.12 & 72.20 & $68.11-76.39$ & 2.89 \\
\hline $55-64$ & 24.56 & $21.12-28.97$ & 7.23 & 53.47 & $48.85-58.32$ & 4.56 & 77.00 & $73.40-80.56$ & 2.54 \\
\hline $65+$ & 29.69 & $23.44-36.02$ & 10.89 & 41.17 & $35.42-47.01$ & 7.59 & 63.44 & $57.54-69.33$ & 4.82 \\
\hline Total & 27.23 & $25.03-29.52$ & 4.24 & 64.41 & $62.11-66.77$ & 1.82 & 71.53 & $68.34-74.68$ & 2.31 \\
\hline \multicolumn{10}{|c|}{ Women (years) } \\
\hline $18-24$ & 22.03 & $16.62-27.44$ & 12.50 & 64.34 & $58.03-70.52$ & 5.02 & 72.00 & $65.20-78.80$ & 4.80 \\
\hline $25-34$ & 20.91 & $17.09-24.68$ & 9.34 & 45.78 & $41.33-50.44$ & 5.01 & 81.60 & $78.24-85.07$ & 2.11 \\
\hline $35-44$ & 25.94 & $22.53-29.19$ & 6.67 & 39.43 & $35.23-43.45$ & 5.44 & 80.90 & $77.77-84.13$ & 2.03 \\
\hline $45-54$ & 29.09 & $25.88-32.32$ & 5.72 & 44.27 & $41.16-47.56$ & 3.67 & 79.52 & $76.22-82.78$ & 2.11 \\
\hline $55-64$ & 24.33 & $20.51-28.04$ & 7.91 & 40.67 & $36.64-44.77$ & 5.22 & 82.56 & $79.55-85.56$ & 1.90 \\
\hline $65+$ & 27.18 & $23.19-31.22$ & 7.55 & 27.22 & $23.58-30.66$ & 6.83 & 69.63 & $65.71-73.55$ & 2.89 \\
\hline Total & 25.31 & $23.14-27.27$ & 3.85 & 45.70 & $43.76-47.48$ & 2.08 & 77.83 & $75.85-79.78$ & 1.27 \\
\hline
\end{tabular}

* high sampling variability, ** unacceptably high sampling variability - can't be applied to the whole population

age. We found that either men or women older than 65 consumed fruits and/or vegetables rarest of all investigated. The difference reached statistical significance in women compared to all younger age groups. In men, the difference was significant only in comparison with the age group of 55-64 years (Table 2).

In men, there were no significant differences in the proportion of people who excessively consumed alcoholic beverages by age, whereas in women this proportion was significantly lower in the oldest age group. We found that the prevalence of smoking significantly declined with age, more so in women than in men. The proportion of people who were physically active in their leisure time at least twice a week was equal in all age groups until age of 65 , and significantly lower in older than 65 years compared to all younger age groups in both sexes (Table 3 ).

Are obesity and health behaviors responsible for the development of obesity socially conditioned? For the purposes of this analysis, the respondents were divided into three socioeconomic groups, graded by the respondents without formal education or with primary school and lowest categories of personal income to $3000 \mathrm{kuna}$, over medium socioeconomic groups, which included respondents with secondary school and personal revenues from 3000 to 5000 kuna, the highest socioeconomic groups of highly educated respondents and the highest earners. By these divisions $72 \%$ of 9070 CAHS participants were included in the analysis of social conditioning of behavioral risks of obesity. The others were excluded because they did not belong in any of the three dominant categories and did not represent a typical pattern, i.e. a negative correlation between educational and income level and risk for development of obesity.

These results suggest that obesity was significantly more prevalent in the lowest socioeconomic class compared with all higher. In Croatia, 26.79\% (95\% CI 24.5129.07) of adults in the category of low socioeconomic status were obese, which is a significantly higher proportion than in the middle social stratum $(15.44 \%, 95 \%$ CI 12.76 18.11), and particularly compared to the group with the highest socioeconomic status $(11.63 \%$, 95\% CI 9.00 14.25). Our analysis of social conditioning of obesity by gender showed that obesity is significantly and distinctly socially conditioned in women, whereas for men the indication of social conditioning has not reached a statistically significant level. 30.31\% (95\% CI 27.83-32.78) of women from the lowest socioeconomic stratum are obese, 2.5 times more than in the middle $(12.77 \%$, 95\% CI 10.55-14.99), and even 3.5 times more than in category of high socioeconomic status (8.62\%, 95\% CI 5.92-10.33). The proportion of obese men was the highest in the lowest socioeconomic stratum and lowest in the highest so- 
TABLE 3

SHARE OF PERSONS WHO EXCESSIVELY CONSUME ALCOHOL, WHO SMOKE, AND RESPONDERS WHO ARE PHYSICALLY ACTIVE IN THEIR LEISURE-TIME IN THE TOTAL ADULT POPULATION OF CROATIA, DISTRIBUTION BY SEX AND AGE

\begin{tabular}{|c|c|c|c|c|c|c|c|c|c|}
\hline & $\begin{array}{c}\text { Persons who } \\
\text { excessively } \\
\text { consume } \\
\text { alcohol }(\%)\end{array}$ & $95 \% \mathrm{CI}$ & $\mathrm{CV}(\%)$ & $\begin{array}{l}\text { People who } \\
\text { smoke }(\%)\end{array}$ & $95 \% \mathrm{CI}$ & $\mathrm{CV}(\%)$ & $\begin{array}{l}\text { Persons who } \\
\text { are physically } \\
\text { active in } \\
\text { leisure time } \\
\text { at least } 2 \mathrm{x} \text { a } \\
\text { week }(\%)\end{array}$ & $95 \% \mathrm{CI}$ & $\mathrm{CV}(\%)$ \\
\hline Total & 18.53 & $11.70-12.38$ & 1.45 & 31.25 & $29.72-32.62$ & 2.30 & 54.33 & $50.73-57.83$ & 3.44 \\
\hline \multicolumn{10}{|l|}{ Men (years) } \\
\hline $18-24$ & 7.98 & $7.42-8.53$ & 3.66 & 46.27 & $37.64-55.14$ & 9.67 & 65.71 & $56.01-75.41$ & 7.50 \\
\hline $25-34$ & 10.48 & $9.62-11.29$ & 3.90 & 49.12 & $40.45-57.75$ & 8.91 & 66.00 & $57.44-74.64$ & 6.67 \\
\hline $35-44$ & 16.29 & $15.44-17.16$ & 2.77 & 44.73 & $38.58-50.88$ & 7.00 & 56.72 & $50.44-63.05$ & 5.73 \\
\hline $45-54$ & 18.14 & $17.08-19.19$ & 3.00 & 39.34 & $33.74-45.04$ & 7.23 & 55.61 & $48.56-62.66$ & 6.42 \\
\hline $55-64$ & 14.56 & $13.96-15.41$ & 2.48 & 28.15 & 23.05-33.35 & 9.43 & 57.26 & $51.36-63.33$ & 5.28 \\
\hline $65+$ & 12.72 & $12.32-13.93$ & 3.17 & 19.72 & $15.47-23.89$ & 11.47 & 41.11 & $33.45-48.55$ & 9.71 \\
\hline Total & 16.54 & $16.10-16.99$ & 1.38 & 37.90 & $35.43-40.45$ & 3.52 & 56.85 & $52.88-60.89$ & 3.64 \\
\hline \multicolumn{10}{|c|}{ Women (years) } \\
\hline 18-24 & 9.10 & $8.05-10.16$ & 5.92 & 35.26 & $28.44-42.24$ & 10.00 & 49.34 & $41.72-56.85$ & 7.80 \\
\hline $25-34$ & 8.17 & $7.60-8.73$ & 3.50 & 38.91 & $34.88-43.02$ & 5.38 & 56.32 & $50.90-61.71$ & 4.88 \\
\hline $35-44$ & 10.00 & $9.71-11.51$ & 4.35 & 33.27 & $30.56-37.35$ & 5.10 & 56.13 & $50.12-62.11$ & 5.55 \\
\hline $45-54$ & 5.64 & $5.21-6.06$ & 3.83 & 27.17 & $24.44-30.15$ & 5.40 & 60.52 & $55.32-65.61$ & 4.25 \\
\hline $55-64$ & 6.30 & $5.86-6.75$ & 3.69 & 17.78 & $14.31-21.31$ & 10.00 & 55.77 & $51.07-60.47$ & 4.42 \\
\hline $65+$ & 10.92 & $9.70-12.17$ & 5.91 & 7.40 & $5.00-9.70$ & 16.50 & 35.43 & $29.73-41.12$ & 8.61 \\
\hline Total & 8.36 & $8.01-8.85$ & 2.54 & 25.15 & $23.66-26.67$ & 3.02 & 51.92 & $47.86-55.88$ & 3.94 \\
\hline
\end{tabular}

cial stratum, but the differences, although present, were not statistically significant. Therefore, obesity in men can not be categorized as a directly socially conditioned disease.

Whereas the proportion of people who drank too much alcohol, and those who were regularly physically active in their leisure time does not vary by socioeconomic group, we found that two of the three studied unhealthy eating habits, mainly using animal fats and insufficient intake of fruits and vegetables were considerably socially conditioned. The total population, as well as men and women separately, showed almost identical negative correlation between the two unhealthy eating habits and belonging to the higher socioeconomic status. Mainly using animal fats in the household and inadequate intake of fruits and vegetables tended to be significantly less present in each higher socioeconomic level compared to all lower. Unlike these two dietary behavioral variables, frequent consumption of cured meats products was significantly more frequent in the middle socioeconomic status, more pronounced when compared with low socioeconomic strata than with a high, but in both cases reaching statistical significance in the overall population and women. Similar pattern was recognized in men, but this difference did not reach statistical significance. Unlike all the other studied behavioral risks, smoking does not show consistent results. Our analysis showed that highly educated men with highest incomes smoked significantly less than the men in lower social groups. The opposite direction was found in women; highly educated women with highest incomes smoked significantly more than women in the middle and low socioeconomic strata (Table 4).

\section{Discussion}

Many believe that obesity is a genetic heritage, and that this heritage responsible for the individual's vulnerability to develop obesity. However, the unexpectedly rapid rise in the prevalence of obesity in different societies and social environments can not be explained exclusively by heredity. It seems that the obesity epidemic results from changes in lifestyle. Modern lifestyle, because of its lower cost, easier preparation and availability of energy-rich foods, increases food consumption. On the other hand, modern lifestyle carries a higher proportion of sedentary jobs and reduced physical activity.

Habits vary with age. A relatively small proportion of persons of both sexes aged over 65 regularly consume fruits and/or vegetables, compared with all other age groups, indicating a significant problem in the nutrition of the elderly. There is a need for additional quantitative and qualitative research to determine causes and possible interventions. A significantly lower proportion of 
TABLE 4

SHARE OF ADULTS WITH OBESITY AND ITS BEHAVIORAL PREDICTORS, DISTRIBUTION BY SOCIO-ECONOMIC GROUPS

\begin{tabular}{|c|c|c|c|c|c|c|c|c|c|c|}
\hline & & \multicolumn{3}{|c|}{ Low socio-economic status } & \multicolumn{3}{|c|}{ Medium socio-economic status } & \multicolumn{3}{|c|}{ High socio-economic statusa } \\
\hline & & $\%$ & $95 \% \mathrm{CI}$ & $\mathrm{CV}(\%)$ & $\%$ & $95 \% \mathrm{CI}$ & $\mathrm{CV}(\%)$ & $\%$ & $95 \% \mathrm{CI}$ & $\mathrm{CV}(\%)$ \\
\hline \multirow[t]{7}{*}{ Total } & $\mathrm{BMI} \geq 30.00 \mathrm{~kg} \mathrm{~m}^{-2}$ & 26.79 & $24.51-29.07$ & 4.35 & 15.44 & $12.76-18.11$ & 8.83 & 11.63 & $9.00-14.25$ & 11.54 \\
\hline & Animal fats & 39.01 & $35.56-42.46$ & 4.51 & 22.63 & $19.57-25.70$ & 6.91 & 10.30 & $7.38-13.22$ & 14.46 \\
\hline & Cured meat & 45.20 & $41.52-48.87$ & 4.15 & 59.73 & $56.81-62.65$ & 2.50 & 50.89 & $45.89-55.90$ & 5.01 \\
\hline & Fruits and vegetables & 64.08 & $60.10-68.07$ & 5.66 & 77.62 & $73.72-81.53$ & 8.90 & 84.96 & $81.78-88.14$ & 10.79 \\
\hline & Alcoholic beverages & 6.65 & $4.85-8.46$ & 13.85 & 9.85 & $7.08-12.62$ & 14.34 & 6.87 & $4.20-9.54$ & 19.82 \\
\hline & Smoking & 23.20 & $20.58-25.82$ & 5.76 & 34.89 & $30.92-38.86$ & 5.81 & 27.07 & $22.55-31.59$ & 8.52 \\
\hline & Physical activity & 50.81 & $45.54-56.08$ & 5.29 & 43.00 & $36.83-49.16$ & 7.32 & 9.00 & $40.80-52.20$ & 6.25 \\
\hline \multirow[t]{7}{*}{ Men } & $\mathrm{BMI} \geq 30.00 \mathrm{~kg} \mathrm{~m}^{-2}$ & 19.95 & $15.14-24.75$ & 12.30 & 18.05 & $13.61-22.48$ & 12.54 & 14.52 & $9.80-19.25$ & 16.16 \\
\hline & Animal fats & 43.97 & $37.86-50.09$ & 7.09 & 25.70 & $20.42-30.97$ & 10.48 & 11.08 & $6.06-16.09$ & 23.09 \\
\hline & Cured meat & 57.03 & $51.06-63.01$ & 5.34 & 67.53 & $61.84-73.22$ & 4.30 & 59.44 & $51.62-67.26$ & 6.72 \\
\hline & Fruits and vegetables & 46.64 & $40.07-53.22$ & 7.19 & 24.25 & $17.40-31.10$ & 14.41 & 17.24 & $11.62-22.86$ & 16.63 \\
\hline & Alcoholic beverages & 17.44 & $12.95-21.93$ & 13.13 & 18.28 & $13.28-23.28$ & 13.95 & 12.09 & $7.23-16.94$ & 20.49 \\
\hline & Smoking & 41.04 & $35.41-46.67$ & 7.00 & 38.30 & $31.65-44.95$ & 8.86 & 27.08 & $19.13-35.02$ & 14.96 \\
\hline & Physical activity & 48.25 & $41.49-55.01$ & 7.15 & 40.55 & $31.48-49.62$ & 11.41 & 45.35 & $37.29-53.42$ & 9.07 \\
\hline \multirow[t]{7}{*}{ Women } & $\mathrm{BMI} \geq 30.00 \mathrm{~kg} \mathrm{~m}^{-2}$ & 30.31 & $27.83-32.78$ & 4.17 & 12.77 & $10.55-14.99$ & 8.87 & 8.62 & $5.90-10.33$ & 16.09 \\
\hline & Animal fats & 36.46 & $33.41-39.52$ & 4.28 & 19.51 & $16.47-22.54$ & 7.93 & 9.50 & $6.47-12.53$ & 16.27 \\
\hline & Cured meat & 39.12 & $35.57-42.67$ & 4.63 & 51.76 & $47.95-55.57$ & 3.75 & 42.03 & $36.48-47.58$ & 6.74 \\
\hline & Fruits and vegetables & 30.41 & $26.94-33.88$ & 5.82 & 20.46 & $17.13-23.79$ & 8.30 & 12.76 & $9.36-16.17$ & 13.59 \\
\hline & Alcoholic beverages & 1.11 & $0.50-1.73$ & 28.11 & 1.25 & $0.44-2.05$ & 32.94 & 1.45 & $0.33-2.58$ & 39.52 \\
\hline & Smoking & 14.05 & $11.73-16.36$ & 8.41 & 31.40 & $27.50-35.30$ & 6.33 & 27.07 & $21.97-32.17$ & 9.61 \\
\hline & Physical activity & 52.12 & $46.51-57.73$ & 5.49 & 45.50 & $40.06-50.94$ & 6.10 & 47.69 & $41.23-54.15$ & 6.91 \\
\hline
\end{tabular}

* high sampling variability, ** unacceptably high sampling variability - can't be applied to the whole population

people aged 65 years or older reported engaging with physical activity in leisure time at least twice a week. One of the possible causes may be a higher prevalence of chronic diseases in this age group, however quite possibly this could also be due to a way of life and environment that makes and supports the recreational activities of the elderly. Most other habits, as expected, were less common in younger age groups.

Younger adults were more likely to eat cured meat products and smoke more, and, in addition, younger women drank more alcoholic beverages, compared with the elderly. These are areas where prevention activities should focus on younger people. This study found that men in younger age groups, below 45 years of age, were more likely to be obese than women of the corresponding age. The reason probably lies in considerably high prevalence of unhealthy behaviors among men in Croatia, which is analyzing the behavioral risk of obesity determined in this study.

In accordance with results of other researchers ${ }^{24-28}$ in Croatia, men have more irregular habits, compared with women. Men are prone to greater consumption of meat products and alcoholic beverages and smoking, and eating less fruits and vegetables. This learned behavior may contribute to higher rates of obesity in younger men, as our study also showed.

The results of our study clearly show that, unlike obesity among men, obesity among women in Croatia is socially conditioned. Similar results were found in the report on the state of the nation's health in the UK conducted in 2003. A significant and very clear positive correlation between obesity and low socioeconomic status was found in women, but in men such association was absent ${ }^{29}$.

In women, obesity is on the one hand socially conditioned, and on the other hand it affects the social component of women's lives. It is possible that these socially determined patterns of obesity have a greater negative impact on social mobility of women, compared with men. This may perhaps hold for the discrimination in employment and even finding a life partner for obese women, compared with obese men of the same age. Also, it is possible that lower social position in itself is a greater risk for developing obesity in women than in men. Two British cohort studies offer some explanation. One reported on research conducted on the 1946 birth cohort and the second on the 1970 birth cohort. The study done on the 1946 birth cohort showed that both men and women who climb the social ladder are less likely to develop obesity, 
compared with people who remain within a same social stratum from childhood throughout their lifetime ${ }^{30}$. The study of the 1970 birth cohort showed that obese women were less likely to find a job adequate to their interests and expectations, as well as to find a life partner. In this study, such associations were not found for obese $\mathrm{men}^{31}$. Another study conducted in Britain showed that women of lower social position have a higher risk for obesity, compared with women of higher socioeconomic status, regardless of age ${ }^{32}$. Women of higher socioeconomic position are more critical to their physical appearance and more concerned about keeping their weight within normal values, as well as keeping regular habits compared with women from lower social strata ${ }^{33}$. Women who migrate from a higher to a lower social stratum are less concerned about maintaining desirable body weight and more satisfied with their physical appearance, compared with women who are climbing the social ladder ${ }^{34}$. Are behavioral risks of obesity socially conditioned? Our analysis of the social conditioning of habits in the adult population in Croatia indicates that health behavior is socially conditioned in both sexes. While the proportion of people who drink too much alcohol and those who are regularly physically active in leisure time does not vary by socioeconomic groups, two of the three studied unhealthy eating habits, mainly using animal fats and insufficient intake of fruits and vegetables, are strongly associated with belonging to a particular socioeconomic grouping, or socially conditioned. Our results for the total population, as for men and women separately, show almost identical negative correlations between the two unhealthy eating habits and belonging to a higher socioeconomic position. Mainly using animal fats in the household and inadequate intake of fruits and vegetables were significantly less present with each higher socioeconomic level compared to all lower. Unlike these two dietary behavioral variables, frequent consumption of cured meats was significantly more common in the group with medium socioeconomic position, which is more pronounced when compared with lower than with a higher socioeconomic stratum. Statistical significance was reached in both cases in the overall population, and for women, whereas in men the same pattern was found but the difference did not reach statistical significance. Unlike all studied behavioral risks, smoking does not show consistent results. While highly educated men with highest income smoke significantly less often than members of the two other socioeconomic groups, highly educated women with highest income smoked significantly more than other women. These results could be explained by the well-known facts that public health campaigns on dietary risks via media are completely ineffective for the population from the lower social strata, and appropriate for members of the higher social strata.

Traditionally oriented health education has not proved to be effective, and it is known that people from lower socioeconomic strata do not respond well to this approach $^{13}$. As such one-dimensional and non-specific prevention programs are for now the only type of pre- venting obesity in Croatia, we expect a further deepening of the differences in behavioral risk between higher and lower social groups of the population. Education about the importance of daily consumption of fruits and vegetables, as well as avoiding the use of animal fat has proven to be effective in the higher, and its effect is absent in people of lower social strata ${ }^{35}$. This will probably only increase the differences in risky health behaviors among members of the different social classes in Croatia. On the other hand, a higher proportion of women who smoke cigarettes and people who drink too much in the higher social categories indicate trends consistent with those observed in other countries, where rates of smoking in men and women are leveling off, and excessive drinking is more widespread in the higher social strata ${ }^{36}$. It is possible that it is a way of relaxation due to higher stress to which women from higher social categories are exposed as businesswomen and mothers and housewives and homemakers. On the other hand, smoking and alcohol in the lower social groups are possibly still not a socially acceptable behavior for women, which is probably why women from lower social groups either deny or really do not smoke and drink alcohol, as much as women of higher position. We saw a trend towards social conditioning of obesity in men, however in our study this did not reach statistical significance. The most significant predictors of obesity in men were older age and frequent consumption of cured meats. Obesity in women in Croatia is socially conditioned. Women with higher levels of education were significantly less likely to develop obesity. And their behavioral risks are socially conditioned. Women in Croatia, older age and frequent intake of hidden fats of animal origin carry a significantly higher risk for obesity, and smoking and each higher level of formal education help reduce the risk of obesity among women in Croatia. For planning public health programs to prevent obesity, it is necessary to know the etiology of obesity, as well as the specificity of sex and territorial determination, which carries cultural and traditional characteristics. In addition, it is important to determine which are really significant risks associated with further activities and act specifically, and focus prevention activities on them. Older age, a variable that can not be acted upon, may be a warning that our population carries an increased risk of developing obesity.

Our findings, which are based on a representative sample of Croatia, show that the most important risk factors for developing obesity are older age and frequent consumption of cured meats, possibly due to "hidden « fats of animal origin that apparently people do not take seriously enough. At the same time, the use of animal fats or vegetable oils does not seem to be the key risk factor for obesity in our population. This result, although unexpected, seems logical. Since only a very low proportion of our respondents indicated mostly using animal fats in cooking, it seems likely that knowledge about the hazards of consuming animal fats are well known in our population; this may have been accomplished through a number of media educational interventions. However, 
any type of fat is a rich energy input, and thus may confer an increased risk for obesity. The difference in intake of animal or vegetable fat may be a key factor in obesity. However, cured meat products, which are rich both in fats and energy, seem to be the as yet not well enough recognized or spoken about risk factor for developing obesity in the general population of Croatia.

\section{Acknowledgements}

This article was prepared as a part of scientific project »Regionalism of cardiovascular behavioural risk factors model of intervention« (108-1080135-0264) supported by Ministry of Science, Education and Sport of the Republic of Croatia.

\section{R E F E R E N C E S}

1. BERKMAN L, BRESLOW L, Health and Ways of Living: The Alameda County Study (Oxford University Press, New York, 1983). - 2. MOKDAD AH, MARKS JS, STROUP DF, GERBERDING JL, JAMA 291 (2004) 1238 - 3. KHAW KT, WAREHAM N, BINGHAM S, PLoS Med, 5 (2008) 12. - 4. SINGH GK, SIAHPUSH M, Int J Epidemiol, 31 (2002) 600. - 5. MEARA ER, RICHARDS S, CUTLER DM, Health Aff (Millwood) 27 (2008) 350 - 6. MACKENBACH JP, BOS V, ANDERSEN O, Int J Epidemiol, 32 (2003) 830. - 7. LYNCH JW, KAPLAN GA, SALONEN JT, Soc Sci Med, 44 (1976) 809. - 8. LAKKA TA, KAUHANEN J, SALONEN JT, Int J Epidemiol, 25 (1996) 86. - 9. MARTIKAINEN P, BRUNNER E, MARMOT M, Soc Sci Med, 56 (2003) 1397 - 10. MACINTYRE S, Soc Sci Med, 44 (1997) 723. - 11. TOWNSEND P, DAVIDSON N, Inequalities in Health: The Black Report (Penguin Books, Harmondsworth, 1982). - 12. LAAKSONEN M, TALALA K, MARTELIN T, Eur J Public Health, 18 (2008) 38. - 13. LANTZ PM, HOUSE JS, LEPKOWSKI JM, JAMA, 279 (1998) 1703-1708. - 14. SCHRIJVERS CT, STRONKS K, VAN DE MHEEN HD, MACKENBACH JP, Am J Public Health, 89 (1999) 535. - 15. STRAND BH, TVERDAL A, J Epidemiol Community Health, 58 (2004) 705. - 16. VAN OORT FV, VAN LENTHE FJ, MACKENBACH JP, J Epidemiol Community Health, 59 (2005) 214. - 17. WOODWARD M, OLIPHANT J, LOWE G, TUNSTALL-PEDOE H, Prev Med, 36 (2003) 561 - 18. NATIONAL HEALTH AND SOCIAL CARE INFORMATION CENTRE, Statistics on Smoking (National Health and Social Care Information Centre, London, 2008). - 19. NATIONAL HEALTH AND SOCIAL CARE INFORMATION CENTRE, Statistics on Obesity, Physica Activity and Diet (Health and Social Care Information Centre, London,
2008). - 20. CHAN RH, GORDON NF, CHONG A, ALTER DA, Am J Cardiol, 102 (2008) 1583. - 21. PURSLOW LR, YOUNG EH, WAREHAM NJ, BMC Public Health, 8 (2008) 112. - 22. RUST K, RAO JNK, Stat Methods Med Res 5 (1996) 281 - 23. YEO D, MANTEL H, LIU TP, Bootstrap variance estimation for the national population survey. In: AMERICAN STATISTICAL ASSOCIATION Proceedings of the Survey Research Methods Section (American Statistical Association, Baltimore, 1999). - 24. BATES CJ, PRENTICE A, FINCH S, Eur J Clin Nutr, 53 (1999) 694. - 25. KUO PH, WOOD P, MORLEY KI, MADDEN P, MARTIN NG, HEATH AC, Drug Alcohol Depend, 88 (2007) 122. - 26. MAKELA P, GMEL G, GRITTNER U, KUENDIG H, KUNTSCHE S, BLOOMFIELD K, Alcohol Alcohol Suppl, 41 (2006) - 27. WARDLE J, HAASE AM, STEPTOE A, NILLAPUN M, JONWUTIWES K, BELLISLE F, Ann Behav Med, 27 (2004) 107. - 28. WESTENHOEFER J, Forum Nutr, 44 (2005) 51. - 29. SPROSTON K, PRIMATESTA P, Health survey for England 2003: Risk factors for cardiovascular disease. (HMSO, London, 2004). - 30. LANGENBERG C, HARDY R, KUH D, BRUNNER E, WADSWORTH M, J Epidemiol Community Health, 57 (2003) 816. 31. VINER RM, COLE TJ, BMJ, 330 (2003) 1354. - 32. PURSLOW LR, YOUNG EH, WAREHAM NJ, FOROUHI N, BRUNNER EJ, LUBEN RN, BMC Public Health, 8 (2008) 112. — 33. WARDLE J, GRIFFITH J, J Epidemiol Community Health, 55 (2001) 185. - 34. SOBAL J, RAUSCHENBACH B, FRONGILLO EA, Soc Sci Med, 56 (2003) 1543. — 35. MARMOT MG, ROSE G, SHIPLEY MJ, HAMILTON PJS, J Epidemiol Community Health, 32 (1978) 244. - 36. KUO PH, WOOD P, MORLEY KI, MADDEN P, MARTIN NG, HEATH AC, Drug Alcohol Depend, 88 (2007) 122.

\section{S. Musić Milanović}

University of Zagreb, School of Medicine, "Andrija Štampar« School of Public Health, Rockefellerova 4, 10000 Zagreb, Croatia

e-mail: sanja.music@hzjz.hr

\section{SOCIJALNA UVJETOVANOST ZDRAVSTVENOG PONAšANJA U ODRASLIH U HRVATSKOJ}

\section{S A $\check{Z}$ E T A K}

Cilj ovog rada bio je istražiti socijalnu uvjetovanost životnih navika, temeljem podataka iz Hrvatske zdravstvene ankete 2003. Presječno istraživanje na reprezentativnom slučajnom uzorku od 9070 odraslih osoba iz Hrvatske pokazalo je da je debljina značajno i vrlo jasno socijalno uvjetovana u žena, dok u muškaraca postoji naznaka socijalne uvjetovanosti, koja međutim nije dosegnula statističku značajnost. Zdravstveno ponašanje socijalno je uvjetovano u oba spola. Životne navike muškaraca u Hrvatskoj nepravilnije su od onih u žena. Češce konzumiraju suhomesnate proizvode, rjeđe voće i povrće, češce prekomjerno piju i puše. Preventivne javnozdravstvene programe vezane uz problem debljine valjalo bi usmjeriti na bihevioralne rizike koji su specifični i po spolu i po socijalnoj pripadnosti. U muškaraca je moguće primijeniti jedinstveni model edukacije, dok su za žene potrebni specifični programi, prilagođeni njihovoj socijalnoj pripadnosti. 